\title{
The effect of calcium intake on bone composition and bone resorption in the young growing rat
}

\author{
Annette Creedon and Kevin D. Cashman* \\ Nutritional Sciences, Department of Food Science, Food Technology \& Nutrition, \\ University College, Cork, Republic of Ireland
}

(Received 9 June 2000 - Revised 25 April 2001 - Accepted 7 May 2001)

\begin{abstract}
A low $\mathrm{Ca}$ intake by both rats and man increases bone resorption, decreases bone mass and increases the risk of osteoporosis. The skeletal effect of high Ca intakes is less clear, particularly during periods of bone mineral accrual. Twenty-four female 5-week-old rats, Wistar strain, were randomized by weight into three groups of eight rats each and fed ad libitum a semi-purified diet containing 2 (Ca-restricted), 5 (normal) or 20 (Ca-supplemented) g Ca/kg for 3 weeks. When compared with the normal $\mathrm{Ca}$ diet, urinary $\mathrm{Ca}$ excretion was unaffected by the dietary restriction of $\mathrm{Ca}$ for 3 weeks, but was greater $(P<0 \cdot 001)$ in Ca-supplemented rats. Urinary pyridinoline $(\mathrm{Pyr})$ and deoxypyridinoline (Dpyr) levels were significantly greater during weeks 2 (Pyr $P<0 \cdot 05$, Dpyr $P<0 \cdot 001$ ) and 3 (Pyr $P<0 \cdot 01$, Dpyr, $P<0 \cdot 001$ ) of dietary Ca restriction, but were unaffected by $\mathrm{Ca}$ supplementation. Femoral dry weight and the concentration of $\mathrm{Mg}$ and $\mathrm{P}$ in femora were unaffected by dietary $\mathrm{Ca}$ concentration. Femoral $\mathrm{Ca}$ concentration was reduced $(P<0 \cdot 05)$ in the Ca-restricted group compared with the other two groups. In conclusion, these results suggest that increasing dietary Ca intake, well above the recommended level, had no effect on bone mineral composition or bone resorption (as assessed with urinary pyridinium crosslinks) in young growing female rats. In addition, these results confirm the findings of previous studies which have shown that bone $\mathrm{Ca}$ content in young growing rats was reduced by dietary $\mathrm{Ca}$ restriction and that this reduction results, at least in part, from an increased rate of bone resorption.
\end{abstract}

Calcium: Pyridinium crosslinks: Bone: Rats

There is evidence that bone mass in early adult life (peak bone mass) is an important factor influencing bone mass and fracture susceptibility in later life (Hui et al. 1989; Melton et al. 1990; Hansen et al. 1991). Thus, achievement of optimal peak bone mass is critical for delaying or preventing osteoporosis (Matkovic et al. 1979; Jackman et al. 1997).

The importance of $\mathrm{Ca}$ intake for the development and maintenance of peak bone mass is well established. A low $\mathrm{Ca}$ intake by both rats and man increases bone resorption (Egger et al. 1994; Shapses et al. 1995; Ginty et al. 1998; Talbott et al. 1998), decreases bone mass (Matkovic et al. 1990; Persson et al. 1993; Talbott et al. 1998) and increases the risk of osteoporosis (Heaney, 1996).

The skeletal effect of high $\mathrm{Ca}$ intakes is less clear, particularly during periods of bone mineral accrual. There is some concern that very high $\mathrm{Ca}$ intakes during the period of growth could potentially interfere with the bone remodelling process. On the other hand, a number of studies have shown that increasing Ca intake (by 300-1000 mg/d, from foods or supplements) above the usual dietary intakes (typically in the range, 300-900 $\mathrm{mg} \mathrm{Ca} / \mathrm{d}$ ) enhances the rate of increase in bone mineral content and bone mineral density in children and adolescents (Johnston et al. 1992; Lloyd et al. 1993; Lee et al. 1994; Chan et al. 1995; Cadogan et al. 1997; Slemenda et al. 1997; Dibba et al. 1998). The Ca levels used in some of these studies were designed to raise levels to the recommended concentration from a baseline of low $\mathrm{Ca}$, whereas in others they raised levels well above the recommended concentration. The higher $\mathrm{Ca}$ intake, if sustained, may lead to a higher peak bone mass at maturity (Institute of Medicine, 1997). The mechanism by which high $\mathrm{Ca}$ intake benefits peak bone mass is thought to be suppression of the remodelling rate which leads to a measurable increase in bone mass over time (Heaney, 1994). However, there have been few studies on the effect of increasing dietary $\mathrm{Ca}$ intake above the usual

Abbreviations: Dpyr, deoxypyridinoline; Pyr, pyridinoline.

* Corresponding author: Professor Kevin Cashman, fax +353 21 4270244, email k.cashman@ucc.ie 
dietary intake on bone turnover, or remodelling, in children and adolescents. Two studies have reported that $\mathrm{Ca}$ supplementation significantly reduced serum levels of osteocalcin, a marker of bone formation, in children and that the reductions in serum osteocalcin with $\mathrm{Ca}$ supplementation were accompanied by greater increases in bone mineral density (Johnston et al. 1992; Dibba et al. 1998, 1999). The effect of Ca supplementation on the rate of bone resorption is less clear. Johnston et al. (1992) found that $\mathrm{Ca}$ supplementation $(1000 \mathrm{mg} / \mathrm{d})$ for 3 years had no effect on serum levels of tartrate-resistant acid phosphatase, a marker of bone resorption, in prepubertal children with a mean usual Ca intake of $900 \mathrm{mg} / \mathrm{d}$. Cadogan et al. (1997) did not observe any change in a number of indicators of bone resorption and bone formation (including serum osteocalcin) in adolescent girls whose mean usual $\mathrm{Ca}$ intake of $746 \mathrm{mg} / \mathrm{d}$ was supplemented daily with an additional $568 \mathrm{ml}$ milk (approximately $660 \mathrm{mg} \mathrm{Ca} / \mathrm{d}$ ) for 18 months, although bone mineral content and density were reported to increase. In the adolescent rat Peterson et al. (1995) found that $\mathrm{Ca}$ supplementation over 8 weeks reduced the rate of bone resorption, as assessed by bone histomorphometry at the tibia, even though tibial bone mineral density was unchanged. There has been no study of the effect of very high $\mathrm{Ca}$ intakes (achievable by diet plus supplemental $\mathrm{Ca}$ ) on bone resorption or bone remodelling in the young growing rat, despite evidence of possible adverse effects on bone development (Persson et al. 1993).

Pyridinium crosslinks, pyridinoline (Pyr) and deoxypyridinoline (Dpyr), are products of the post-translational modification of collagen, and their urinary excretion has been used as a specific and sensitive index of bone resorption in man (Eyre, 1992; Robins \& New, 1997) and rats (Black et al. 1989; Egger et al. 1994). Low Ca intakes by both rats (Egger et al. 1994; Talbott et al. 1999) and man (Shapses et al. 1995; Ginty et al. 1998) have been shown to

Table 1. Composition of the modified AIN-76 diet (American Institute of Nutrition, 1977)

\begin{tabular}{lc}
\hline Ingredient & Content $(\mathrm{g} / \mathrm{kg})$ \\
\hline Casein & $200 \cdot 0$ \\
DL-Methionine & $3 \cdot 0$ \\
Maize starch & $150 \cdot 0$ \\
Sucrose & $495 \cdot 0,487 \cdot 5,450 \cdot 0^{*}$ \\
Fibre & $50 \cdot 0$ \\
Maize oil & $50 \cdot 0$ \\
AIN mineral mix† & $35 \cdot 0$ \\
AIN vitamin mix & $10 \cdot 0$ \\
Calcium carbonate & $5 \cdot 0,12 \cdot 5,50 \cdot 0^{*}$ \\
Choline bitartrate & $2 \cdot 0$ \\
\hline
\end{tabular}

${ }^{*}$ Representing diets containing ( $/ \mathrm{kg}$ ) 2.0 (Ca-restricted), 5.0 (normal) or $20 \cdot 0$ (Ca-supplemented) g Ca respectively.

†Containing $(\mathrm{g} / \mathrm{kg})$ : potassium dihydrogen phosphate 376 , dipotassium hydrogen phosphate 160 , sodium chloride 74 , magnesium oxide 24 , manganous carbonate $3 \cdot 5$, ferric citrate 6 , zinc carbonate $1 \cdot 6$, cupric carbonate 0.3 , potassium iodate 0.01 , sodium selenite 0.01 , chromium potassium sulfate 0.55 , sucrose 354 .

$\ddagger$ Containing $(/ \mathrm{kg})$ : nicotinic acid $3 \mathrm{~g}$. calcium pantothenate $1.6 \mathrm{~g}$, riboflavin $600 \mathrm{mg}$, thiamin hydrochloride $600 \mathrm{mg}$, pyridoxine hydrochloride $700 \mathrm{mg}$, pteroylmonoglutamic acid $200 \mathrm{mg}$, biotin $20 \mathrm{mg}$, cyanocobalamin $1 \mathrm{mg}$ cholecalciferol $2.5 \mathrm{mg}$, menaquinone $5.0 \mathrm{mg}$, retinyl palmitate $120 \mathrm{mg}$, $\mathrm{DL}-\alpha$-tocopheryl acetate $5000 \mathrm{mg}$. increase the level of excretion of these pyridinium crosslinks in urine.

The aim of the present study was to investigate the effect of increasing $\mathrm{Ca}$ intake to a high level on bone mineral composition and on pyridinium crosslinks of collagen, using the young growing female rat as a model. In addition, the effect of moderate restriction of dietary $\mathrm{Ca}$ on these variables was also re-evaluated. The juvenile rat is an acceptable model for skeletal studies as it shows the same biological mechanisms for bone growth, bone modelling and remodelling as in children and adolescents (Kalu, 1991; Frost \& Jee, 1992; Peterson et al. 1995).

\section{Materials and methods \\ Preparation of rat diets}

The AIN-76 purified diet (American Institute of Nutrition, 1977) was used in the present study (Table 1).

\section{Experimental design}

Twenty-four female Wistar rats, 5 weeks old (average weight $102 \mathrm{~g}$ ), obtained from the Biological Services Unit, University College, Cork, Republic of Ireland were randomized by weight into three groups of eight rats each. The three groups were fed ad libitum on semi-purified diets (AIN-76) containing 2.0 (Ca-restricted), 5.0 (normal), or 20.0 (Ca-supplemented) $\mathrm{g} \mathrm{Ca} / \mathrm{kg}$ for $21 \mathrm{~d}$. Rats were housed individually in metabolism cages with a grid-floor and a facility for separate collection of faeces and urine. Feed was provided at 17.00 hours each day and all animals were given distilled water ad libitum for the duration of the study. Rats were weighed weekly. Urine samples $(24 \mathrm{~h})$ were collected for each animal during the last $3 \mathrm{~d}$ of each week of the study in vessels covered with $\mathrm{Al}$ foil to prevent degradation of the pyridinium crosslinks by light. The urine samples for each animal were pooled and the volumes recorded. Portions of the pooled urine samples were acidified with $12 \mathrm{M}-\mathrm{HCl}(225 \mu \mathrm{l} / 100 \mathrm{ml}$ urine $)$ and stored at $-20^{\circ} \mathrm{C}$ until required for analysis.

After $21 \mathrm{~d}$ on the respective diets, all animals were killed by over-exposure to diethyl ether, and final body weights were recorded. The right femora were harvested and cleaned of adhering soft tissue. The femora were dried overnight at $110^{\circ} \mathrm{C}$, weighed and stored in sealed containers until required for mineral analysis.

\section{Experimental techniques}

Urinary pyridinoline and deoxypyridinoline. Pooled urine samples were analysed in duplicate using a three-step procedure. Aliquots $(250 \mu \mathrm{l})$ of pooled urine samples were hydrolysed with an equal volume of $12 \mathrm{M}-\mathrm{HCl}$ at $110^{\circ} \mathrm{C}$ for $18 \mathrm{~h}$. The crosslinks from the urine hydrolysates were then extracted by CF1 cellulose chromatography with the use of an internal standard (acetylated pyridinoline; MetraBiosystems Ltd, Wheatley, Oxon., UK) and were measured using a reversed-phase HPLC method with fluorescence detection (Colwell et al. 1993). The acetylated pyridinoline was used in accordance with the method described by Calabresi et al. 
(1994) and Robins et al. (1994). The crosslink contents of urine samples were quantified by external standardization using a commercially-available Pyr-Dpyr HPLC calibrator (MetraBiosystems Ltd). The intra-assay CV for Pyr and Dpyr measured as the variation between ten chromatograms obtained between column regenerations as described by Colwell et al. (1993) were 6 and $9 \%$ respectively. The interassay $\mathrm{CV}$ for Pyr and Dpyr were 7 and $8 \%$ respectively.

Femoral calcium, phosphorus and magnesium and urinary calcium levels. Weighed femora (dried) were digested in $10 \mathrm{ml} 16 \mathrm{M}-\mathrm{HNO}_{3}-12 \mathrm{M}-\mathrm{HClO}_{4}(2: 1, \mathrm{v} / \mathrm{v})$ on a hot plate (S \& J Juniper \& Co., Harlow, Essex, UK) until the sample colour resembled that of the reagent blank. $\mathrm{Ca}$ and $\mathrm{Mg}$ were analysed in duplicate in femoral digests by atomic absorption spectrophotometry (Pye-Unicam Atomic Absorption Spectrophotometer, Model SP9; Pye Unicam, Cambridge, Cambs., UK) after appropriate dilution with $\mathrm{LaCl}_{3}$ solution ( $5 \mathrm{~g} / \mathrm{l}$; BDH Ltd, Poole, Dorset, UK). Ca was analysed in duplicate in urine by atomic absorption spectrophotometry after appropriate dilution with the $\mathrm{LaCl}_{3}$ solution. A range of $\mathrm{Ca}$ and $\mathrm{Mg}$ standards was used to obtain $\mathrm{Ca}$ and $\mathrm{Mg}$ calibration curves. The intra- and interassay $\mathrm{CV}$ for $\mathrm{Ca}$ were 2.8 and $7.8 \%$, and for $\mathrm{Mg}$ were 3.2 and $8.8 \%$ respectively. $\mathrm{P}$ was determined in the femoral digests by the method of Weissman \& Pileggi (1974). The intra- and interassay $\mathrm{CV}$ for $\mathrm{P}$ were 4.2 and $6.1 \%$ respectively.

\section{Statistical methods}

Data are presented as means with their standard errors. All data were subjected to one-way ANOVA, with variation attributed to dietary Ca (Snedecor \& Cochran, 1967). To follow up the ANOVA, all pairs of means were compared by the method of least significant difference (Snedecor \& Cochran, 1967).

\section{Results}

Mean body-weight gain did not differ among groups (Fig. 1). The influence of dietary $\mathrm{Ca}$ concentration on urinary $\mathrm{Ca}$, Pyr and Dpyr levels is shown in Table 2. Urinary $\mathrm{Ca}$ excretion was unaffected by the dietary restriction of $\mathrm{Ca}$ to $2 \cdot 0 \mathrm{~g} / \mathrm{kg}$ diet for 3 weeks. Urinary $\mathrm{Ca}$ excretion was greater in the Ca-supplemented group compared with the normal and $\mathrm{Ca}$-restricted groups. While unaffected during week 1, urinary Pyr and Dpyr levels were significantly greater during weeks $2(P<0 \cdot 05$, $P<0.001$ respectively) and $3(P<0.01, P<0.001$ respectively) of $\mathrm{Ca}$ restriction. Urinary $\mathrm{Pyr}$ and Dpyr were unaffected by $\mathrm{Ca}$ supplementation for 3 weeks.

The influence of dietary $\mathrm{Ca}$ concentration on femoral dry weight and macromineral $(\mathrm{Ca}, \mathrm{Mg}$ and $\mathrm{P})$ concentrations is shown in Table 3. Femoral dry weight and the concentration of $\mathrm{Mg}$ and $\mathrm{P}$ in femora were unaffected by dietary $\mathrm{Ca}$ concentration. Femoral $\mathrm{Ca}$ concentration was reduced in the Ca-restricted group compared with the normal and Ca-supplemented groups, with no significant difference in femoral $\mathrm{Ca}$ concentration between the last two groups. 


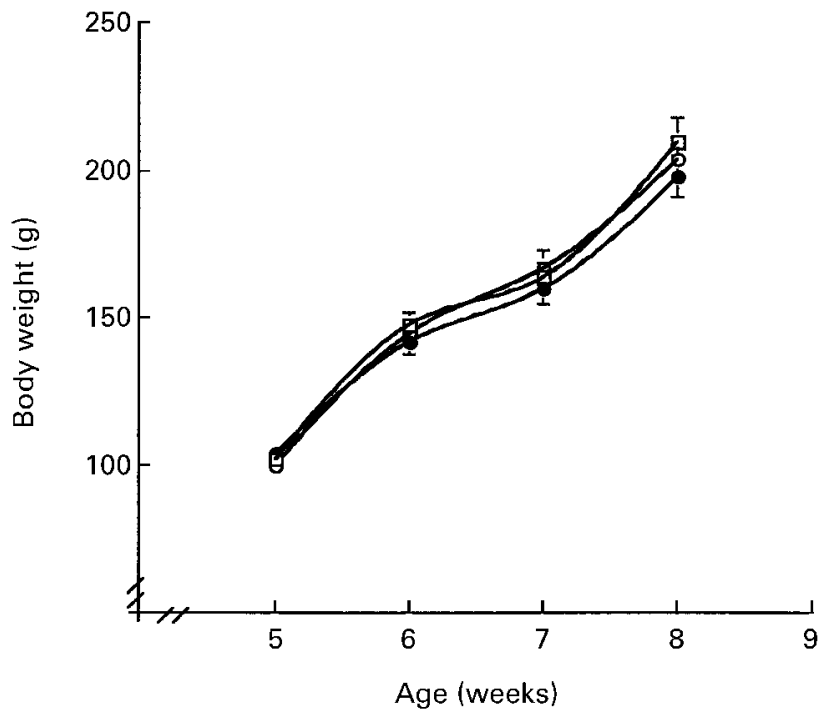

Fig. 1. Body weights over time in rats fed on diets containing different levels of calcium. Groups were: $(\square)$, normal calcium diet; $(\bullet)$, Ca-restricted diet; (O), Ca-supplemented diet. Values are means with their standard errors represented by vertical bars for eight rats. No significant differences were found between groups at any of the time points (by ANOVA, $P<0.05$ ). For details of diets, see Table 1.

\section{Discussion}

In the present study, mean body-weight gain by young growing rats was unaffected by dietary $\mathrm{Ca}$ concentration. This finding is in agreement with those of other studies (Thomas et al. 1988, 1991; Takeda et al. 1993; Peterson et al. 1995; Talbott et al. 1999), but not all (Persson et al. 1993), which have examined the effect of dietary $\mathrm{Ca}$ on weight gain in the rat. Increasing dietary $\mathrm{Ca}$ concentration to a high level $(20 \mathrm{~g} / \mathrm{kg}$ diet $)$ significantly $(P<0 \cdot 05)$ increased urinary $\mathrm{Ca}$ excretion in rats in the present study. On the other hand, restricting dietary $\mathrm{Ca}$ intake to a low level $(2.0 \mathrm{~g} / \mathrm{kg}$ diet $)$ had no effect on urinary Ca excretion. These findings are consistent with the results of previous studies (Makynen et al. 1995; Cashman \& Flynn, 1996). The elevated urinary $\mathrm{Ca}$ levels in rats on the high-Ca diet in the present study probably reflected a greatly increased absolute absorption of $\mathrm{Ca}$ by these rats. For example, Cashman \& Flynn (1996) showed that absolute Ca absorption from a
$10 \mathrm{~g}$ meal in rats fed habitually on diets containing 20, 5 and $2 \mathrm{~g} \mathrm{Ca} / \mathrm{kg}$ diet was 36.9, 24.2 and $17 \cdot 8 \mathrm{mg}$ Ca respectively. A similar response of urinary $\mathrm{Ca}$ to a high dietary $\mathrm{Ca}$ intake has been noted in man (Ginty et al. 1998).

In the present study moderate dietary restriction of $\mathrm{Ca}$ reduced femur $\mathrm{Ca}$ concentration, but had no effect on femoral dry weight or on the $\mathrm{Mg}$ or $\mathrm{P}$ content of the femur. A reduced femoral $\mathrm{Ca}$ level, but not $\mathrm{Mg}$ or $\mathrm{P}$ levels, arising from an increased rate of bone resorption has also been noted in a recent study in which young growing rats were fed a high-salt diet (Creedon \& Cashman, 2000). It may be that, as suggested by Goulding \& Gold (1988), the duration of the present study was too short to elicit significant osteopenia. Several studies have shown that bone $\mathrm{Ca}$ content (Thomas et al. 1988, 1991 Persson et al. 1993; Takeda et al. 1993; Peterson et al. 1995), bone strength (Thomas et al. 1988, 1991) and bone density (Persson et al. 1993; Talbott et al. 1998) in young growing rats were reduced by dietary $\mathrm{Ca}$ restriction (i.e. in the range $0.3-2.5 \mathrm{~g}$ $\mathrm{Ca} / \mathrm{kg}$ diet). Such skeletal alterations may have arisen because of an increased rate of bone resorption or a reduced rate of bone formation and mineralization, or both, secondary to $\mathrm{Ca}$ restriction.

In the present study, moderate dietary restriction of $\mathrm{Ca}$ increased the rate of bone resorption, as measured by the urinary excretion of pyridinium crosslinks of collagen which are regarded as specific markers of bone resorption in rats (Black et al. 1989; Egger et al. 1994). This finding is in agreement with the findings of other studies that reported increased excretion of urinary pyridinium crosslinks (Egger et al. 1994; Talbott et al. 1999) and $\left[{ }^{3} \mathrm{H}\right]$ tetracycline (Egger et al. 1994; Talbott et al. 1998, 1999), another marker of bone resorption, in Ca-restricted young rats. Recently, Talbott et al. (1999) found that 20-week-old female rats fed a diet containing $1 \mathrm{~g} \mathrm{Ca} / \mathrm{kg}$ diet had significantly $(P<0 \cdot 05)$ higher mean urinary Pyr and Dpyr levels (over 9 weeks) compared with rats fed a diet containing $5 \mathrm{~g} \mathrm{Ca} / \mathrm{kg}$ diet. As a marker of bone formation, such as serum osteocalcin or bone-specific alkaline phosphatase, was not included in the present study, it is not clear whether the increased rate of bone resorption reflected an increased rate of bone turnover (i.e. bone resorption and formation). An increased rate of bone turnover has been associated with a reduction in bone mass (Hansen et al. 1991) and disruption of the trabecular network (Parfitt, 1984).

Table 3. Effect of dietary calcium concentration on femur dry weight and concentrations of calcium, magnesium and phosphorus in young growing female rats*

(Mean values with their standard errors for eight rats per group)

\begin{tabular}{|c|c|c|c|c|c|c|c|c|c|}
\hline \multirow[b]{2}{*}{ Group } & \multirow[b]{2}{*}{ Dietary Ca (g/kg) } & \multicolumn{2}{|c|}{ Dry wt (mg) } & \multicolumn{2}{|c|}{$\begin{array}{l}\mathrm{Ca}(\mathrm{mg} / \mathrm{g} \\
\text { dry wt) }\end{array}$} & \multicolumn{2}{|c|}{$M g \underset{w t)}{(m g / g}$ dry } & \multicolumn{2}{|c|}{$P\left(\begin{array}{c}\mathrm{mg} / \mathrm{g} \\
\mathrm{wt})\end{array}\right.$} \\
\hline & & Mean & SE & Mean & SE & Mean & SE & Mean & SE \\
\hline Ca-restricted & $2 \cdot 0$ & $274^{\mathrm{a}}$ & 10 & $266^{a}$ & 4 & $3.84^{a}$ & 0.33 & $104 \cdot 9^{a}$ & $2 \cdot 4$ \\
\hline Normal Ca & $5 \cdot 0$ & $277^{\mathrm{a}}$ & 13 & $286^{\mathrm{b}}$ & 5 & $3 \cdot 76^{\mathrm{a}}$ & 0.27 & $103.4^{\mathrm{a}}$ & $2 \cdot 2$ \\
\hline Ca-supplemented & $20 \cdot 0$ & $279^{a}$ & 18 & $287^{\mathrm{b}}$ & 3 & $3.80^{\mathrm{a}}$ & 0.23 & $105 \cdot 6^{a}$ & $2 \cdot 8$ \\
\hline ANOVA (one-way), $P$ value & & \multicolumn{2}{|c|}{0.417} & \multicolumn{2}{|c|}{0.029} & \multicolumn{2}{|c|}{0.983} & \multicolumn{2}{|c|}{0.813} \\
\hline
\end{tabular}

\footnotetext{
${ }^{a, b}$ Mean values within a column with different superscript letters were significantly different (ANOVA followed by least significant difference test; $P<0.05)$.
}

${ }^{*}$ For details of diets and procedures, see Table 1 and pp. 454-455. 
An increased rate of bone resorption, as assessed by bone histomorphometry, in young rats fed a Ca-restricted diet has also been reported by Peterson et al. (1995). In their study, young (4-week-old) female rats fed a diet containing $2.5 \mathrm{~g}$ $\mathrm{Ca} / \mathrm{kg}$ diet for 8 weeks had higher rates of bone resorption compared with rats fed diets containing 5 and $10 \mathrm{~g} \mathrm{Ca} / \mathrm{kg}$ diet. Furthermore, in addition to the increased rate of bone resorption, dietary restriction of $\mathrm{Ca}$ led to reduced rates of bone formation, mineral apposition and longitudinal growth, and to reduced trabecular number and bone volume (Peterson et al. 1995). If low Ca intakes during adolescence in man leads to elevated rates of bone resorption, as it appears to do in rats, then this increase may have a deleterious effect on peak bone mass.

In the present study increasing the dietary $\mathrm{Ca}$ content to fourfold the requirement had no effect on femoral dry weight or on femoral $\mathrm{Ca}, \mathrm{Mg}$ or $\mathrm{P}$ concentrations. This finding is in agreement with those of Peterson et al. (1995) which showed that increasing the dietary $\mathrm{Ca}$ content to twofold the requirement had no effect on bone mass and $\mathrm{Ca}$ content in young growing rats. Persson et al. (1993), on the other hand, reported that increasing the dietary Ca content to tenfold the requirement impaired bone development (i.e. bone wet weight, ash weight and bone density) in young growing rats. In the present study the rate of bone resorption, as assessed by the urinary pyridinium crosslinks, was unaffected by $\mathrm{Ca}$ supplementation for 3 weeks. In contrast, Peterson et al. (1995) reported that the rate of bone resorption, as assessed by bone histomorphometry, was reduced by a doubling of the recommended $\mathrm{Ca}$ intake of young growing female rats over 8 weeks. However, despite the reduction in the rate of bone resorption, there was no effect of $\mathrm{Ca}$ supplementation on the rate of bone formation or mineral apposition, or on bone volume (Peterson et al. 1995). The reasons for the discordant findings of the present study and that of Peterson et al. (1995) are unclear. Peterson et al. (1995) fed rats a high-Ca diet for a longer period than that in the present study. It is also possible that the urinary pyridinium crosslink assay for determining the rate of bone resorption is a less-sensitive technique compared with bone histomorphometry.

While increasing the $\mathrm{Ca}$ intake to high levels $\left(\right.$ as $\left.\mathrm{CaCO}_{3}\right)$ had no effect on bone resorption in the present study, it may lead to a reduction in the intestinal absorption of $\mathrm{Mg}$ (Greger et al. 1981) and P (Institute of Medicine, 1997), which may have adverse consequences for bone metabolism. However, interactions between high levels of $\mathrm{Ca}$ and $\mathrm{Mg}$ or $\mathrm{P}$ have not shown evidence of depletion of the affected nutrient (Shils, 1994). Furthermore, no depletion of either femoral $\mathrm{Mg}$ or femoral $\mathrm{P}$ was evident in rats fed the high-Ca diet in the present study.

The current criterion of the National Research Council (1978) for determining the Ca requirement of the rat is the level of $\mathrm{Ca}$ needed for maximum mineralization of bone during growth. The method typically employed in this determination is the measurement of bone weight, bone ash and total bone Ca (Bernhart et al. 1969; National Research Council, 1978). Urinary pyridinium crosslinks were utilized in the present study in order to provide better interpretation of the bone mineral composition data, but also because biochemical markers of bone turnover, such as the pyridinium crosslinks, have been suggested as being of potential use in predicting the long-term effects of $\mathrm{Ca}$ on bone turnover and bone mass and, thus, in defining optimal Ca intakes (Cashman \& Flynn, 1999). Interestingly, the pyridinium crosslink data from the present study support the National Research Council (1978) Ca requirement for the rat $(5 \mathrm{~g} \mathrm{Ca} / \mathrm{kg}$ diet $)$. In addition, the findings of the present study lend further support to the hypothesis that $\mathrm{Ca}$ is a threshold nutrient (i.e. at suboptimal intakes the ability of the organism to store $\mathrm{Ca}$ as bone tissue is limited by the intake of $\mathrm{Ca}$, but increasing $\mathrm{Ca}$ intake above that required as optimal for genetic or mechanical purposes does not lead to increased storage of $\mathrm{Ca}$ ).

In conclusion, the findings of the present study confirm the findings of previous studies that have shown that bone $\mathrm{Ca}$ content in young growing rats was reduced by dietary $\mathrm{Ca}$ restriction, and that this reduction results, at least in part, from an increased rate of bone resorption. In addition, increasing dietary $\mathrm{Ca}$ intake above the recommended level had no effect on bone mineral composition or on bone resorption, as assessed with urinary pyridinium crosslinks of collagen, in young growing female rats. These findings would suggest that high $\mathrm{Ca}$ intake levels, well in excess of requirements, may not have detrimental effects on the bone remodelling process, at least in the short term. The utilization of the pyridinium crosslinks of collagen (as markers of bone resorption), as well as inclusion of a marker of bone formation (such as osteocalcin or bone-specific alkaline phosphatase) in future Ca supplementation trials in children and adolescents would greatly extend our knowledge of the effect on bone turnover of increasing dietary $\mathrm{Ca}$ intakes above usual levels.

\section{Acknowledgements}

This research has been part-funded by grant aid under the Food Sub-Programme of the Operational Programme for Industrial Development, which is administered by the Department of Agriculture and Food, Dublin, and supported by national and EU funds.

\section{References}

American Institute of Nutrition (1977) Report of the American Institute ad hoc committee on standards for nutritional studies. Journal of Nutrition 107, 1340-1348.

Black D, Farqharson C \& Robins SP (1989) Excretion of pyridinium crosslinks of collagen in ovariectomized rats as urinary markers for increased bone resorption. Calcified Tissue International 44, 343-347.

Bernhart FW, Savanini S \& Tomarelli RM (1969) Calcium and phosphorus requirements for maximal growth and mineralization of the rat. Journal of Nutrition $\mathbf{9 8}$, 443-448.

Cadogan J, Eastell R, Jones N \& Barke ME (1997) Milk intake and bone mineral acquisition in adolescent girls: randomised, controlled intervention trial. British Medical Journal 315, $1255-1260$.

Calabresi E, Lasagni L, Franceschelli F, Bartolini L \& Serio M (1994) Use of an internal standard to measure pyridinoline and deoxypyridinoline in urine (letter). Clinical Chemistry $\mathbf{4 0}$, $336-337$. 
Cashman K \& Flynn A (1996) Effect of dietary calcium intake and meal calcium content on calcium absorption in the rat. British Journal of Nutrition 76, 463-470.

Cashman K \& Flynn A (1999) Optimal nutrition: calcium, magnesium and phosphorus. Proceedings of the Nutrition Society 58, 477-487.

Chan GM, Hoffman K \& McMurray M (1995) Effects of dairy products on bone and body composition in pubertal girls. Journal of Pediatrics 126, 551-556.

Colwell R, Russell RGG \& Eastell R (1993) Factors affecting the assay of urinary 3-hydroxypyridinium cross-links of collagen as markers of bone resorption. European Journal of Clinical Investigation 23, 341-349.

Creedon A \& Cashman KD (2000) The effect of high salt and high protein intake on calcium metabolism, bone composition and bone resorption in the rat. British Journal of Nutrition 84, 49-56.

Dibba B, Prentice A, Poskitt EME \& Cole TJ (1998) Calcium supplementation increases the bone mineral status of Gambian children. Proceedings of the Nutrition Society 57, 73A.

Dibba B, Prentice A, Stirling D \& Poskitt EME (1999) Effect of calcium supplementation on plasma osteocalcin concentration of Gambian children. Proceedings of the Nutrition Society 58, $61 \mathrm{~A}$.

Egger CD, Mühlbauer RC, Felix R, Delmas PD, Marks SC \& Fleisch H (1994) Evaluation of urinary pyridinium crosslink excretion as a marker of bone resorption in the rat. Journal of Bone and Mineral Research 9, 1211-1219.

Eyre DR (1992) New biomarkers of bone resorption. Journal of Clinical Endocrinology and Metabolism 74, 470A-470C.

Frost HM \& Jee WSS (1992) On the rat model of human osteopenias and osteoporoses. Bone and Mineral 18, 227-236.

Ginty F, Flynn A \& Cashman K (1998) The effect of short-term calcium supplementation on biochemical markers of bone metabolism in healthy young adults. British Journal of Nutrition 80, 437-443.

Goulding A \& Gold E (1988) Effects of dietary $\mathrm{NaCl}$ supplementation on bone synthesis of hydroxyproline, urinary hydroxyproline excretion and bone ${ }^{45} \mathrm{Ca}$ uptake in the rat. Hormone and Metabolic Research 20, 743-745.

Greger JL, Smith SA \& Snedeker SM (1981) Effect of dietary calcium and phosphorus levels on the utilization of calcium, phosphorus, magnesium, maganese, and selenium by adult males. Nutrition Research 1, 315-325.

Hansen MA, Overgaard K, Riis BJ \& Christiansen C (1991) Role of peak bone mass and bone loss in postmenopausal osteoporosis: 12 year study. British Medical Journal 303, 961-964.

Heaney RP (1994) The bone-remodelling transient: implications for the interpretation of clinical studies of bone mass change. Journal of Bone Mineral Research 9, 1515-1523.

Heaney RP (1996) Bone mass, nutrition and other lifestyle factors. Nutrition Reviews 54, S3-S10.

Hui SL, Slemenda CW \& Johnston CC Jr (1989) Baseline measurement of bone mass predicts fracture in white women. Annals of Internal Medicine 111, 355-361.

Institute of Medicine (1997) Dietary Reference Intakes: Calcium, Magnesium, Phosphorus, Vitamin D, and Fluoride. Washington, DC: Food and Nutrition Board, National Academy Press.

Jackman LA, Millane SS, Martin BR, Wood OB, McCabe GP, Peacock M \& Weaver CM (1997) Calcium retention in relation to calcium intake and postmenarcheal age in adolescent females. American Journal of Clinical Nutrition 66, 327-333.

Johnston CC, Miller JZ, Slemenda CW, Reister TK, Hui S, Christian JC \& Peacock M (1992) Calcium supplementation and increases in bone mineral density in children. New England Journal of Medicine 327, 82-87.
Kalu DN (1991) The ovariectomized rat model of postmenopausal bone loss. Bone and Mineral 15, 175-192.

Lee WTK, Leung SSF, Wang SH, Xu YC, Zeng WP, Lau J, Oppenheimer SJ \& Cheng JCY (1994) Double-blind, controlled calcium supplementation and bone mineral accretion in children accustomed to a low-calcium diet. American Journal of Clinical Nutrition 60, 744-750.

Lloyd T, Andon MB, Rollings N, Martel JK, Landis JR, Demers LM, Eggli DF, Kieselhorst K \& Kulin HE (1993) Calcium supplementation and bone mineral density in adolescent girls. Journal of the American Medical Association 270, 841-844.

Makynen H, Kahonen M, Arvola P, Wuorela H, Vapaatalo H \& Porsti I (1995) Dietary calcium and magnesium supplements in spontaneously hypertensive rats and isolated arterial reactivity. British Journal of Pharmacology 115, 1455-1462.

Matkovic V, Fontana D, Tominac C, Goel P \& Chesnut CH III (1990) Factors that influence peak bone mass formation: A study of calcium balance and the inheritance of bone mass in adolescent females. American Journal of Clinical Nutrition $\mathbf{5 2}$, 878-888.

Matkovic V, Kostial K, Simonovic I, Buzina R, Brodarec A \& Nordin BEC (1979) Bone status and fracture rates in two regions of Yugoslavia. American Journal of Clinical Nutrition 32, $540-549$

Melton JL III, Eddy DM \& Johnston CC Jr (1990) Screening for osteoporosis. Annals of Internal Medicine 112, 516-528.

National Research Council (1978) Nutrient Requirements of Laboratory Animals, 3rd ed. Washington, DC: National Academy of Sciences.

Parfitt AM (1984) Age-related structural changes in trabecular and cortical bone: Cellular mechanisms and biomechanical consequences. Calcified Tissue International 36, S123-S128.

Persson P, Gagnemo-Persson R \& Hakanson R (1993) The effect of high or low dietary calcium on bone and calcium homeostasis in young male rats. Calcified Tissue International 52, 460-464.

Peterson CA, Eurell JA \& Erdman JW Jr (1995) Alterations in calcium intake on peak bone mass in the female rat. Journal of Bone and Mineral Research 10, 81-95.

Robins SP \& New SA (1997) Markers of bone turnover in relation to bone health. Proceedings of the Nutrition Society 56, 903-914.

Robins SP, Stead DA \& Duncan A (1994) Precautions in using an internal standard to measure pyridinoline and deoxypyridinoline in urine (letter). Clinical Chemistry 40, 2322-2323.

Shapses SA, Robins SP, Schwartz EI \& Chowdhury H (1995) Short-term changes in calcium but not protein intake alter the rate of bone resorption in healthy subjects as assessed by urinary pyridinium cross-link excretion. Journal of Nutrition 125, 2814-2821.

Shils ME (1994) Magnesium. In Modern Nutrition in Health and Disease, pp. 164-184 [ME Shils, JA Olson and M Shike, editors]. Philadelphia, PA: Lea \& Febiger.

Slemenda CW, Peacock M, Hui S, Zhou L \& Johnston CC (1997) Reduced rates of skeletal remodelling are associated with increased peak bone mineral density during the development of peak skeletal mass. Journal of Bone and Mineral Research 12, 676-682.

Snedecor GW \& Cochran WG (1967) Statistical Methods. Ames, IA: Iowa State University Press.

Takeda T, Kimura M \& Itokawa Y (1993) Imbalance of calcium, magnesium, and phosphorus in bone and other tissues of rats induced by low protein and calcium deficiency. Journal of Nutritional Science and Vitaminology 39, 355-363.

Talbott SM, Chowdhury H \& Shapses SA (1999) Urinary ${ }^{3} \mathrm{H}$-tetracycline and pyridinium crosslinks differ in their response to calcium restriction in mature and aged rats. Calcified Tissue International 64, 352-356. 
Talbott SM, Rothkopf MM \& Shapses SA (1998) Dietary restriction of energy and calcium alters bone turnover and density in younger and older female rats. Journal of Nutrition 128, 640-645.

Thomas ML, Ibarra MJ, Solcher B, Wetzel S \& Simmons DJ (1988) The effect of low dietary calcium and calcium supplements on calcium metabolism and bone in the immature growing rat. Bone and Mineral 4, 73-82.
Thomas ML, Simmons DJ, Kidder L \& Ibarra MJ (1991) Calcium metabolism and bone mineralization in female rats fed diets marginally sufficient in calcium: effects of increased dietary calcium intake. Bone and Mineral 12, 1-14.

Weissman N \& Pileggi VJ (1974) Inorganic ions. In Clinical Chemistry: Principles and Techniques, pp. 639-755 [RJ Henry, DC Cannon and JW Winkelman, editors]. Hagerstown, MD: Harper and Row. 